\title{
Efecto de la adición de ceniza de lodo de depuradora (CLD) en las propiedades mecánicas y niveles de corrosión de las armaduras embebidas en morteros de cemento Portland
}

\section{Effect of sewage sludge ash (SSA) on the mechanical performance and corrosion levels of reinforced Portland cement mortars}

\author{
E. G. a Alcocel(*), P. Garcés(**), J. J. Martínez ${ }^{(* *)}$, J. Payá(***) y L. G. a Andión(**)
}

Recepción/Received: 29-VII-05

Aceptación/Accepted: 09-II-06

\section{RESUMEN}

Se ha estudiado el nivel de corrosión que presentan las armaduras embebidas en morteros fabricados con cemento Portland (CP) con diferentes porcentajes de sustitución de ceniza de lodo de depuradora (CLD). Se ha utilizado la técnica de la Resistencia a la Polarización para determinar la velocidad de corrosión del acero embebido en las muestras estudiadas. Las muestras se han sometido a diferentes condiciones ambientales y agentes agresivos: $100 \%$ de humedad relativa (HR), carbonatación acelerada al 70\% HR e inmersión en agua de mar. Para la fabricación de los distintos morteros, el cemento Portland ha sido parcialmente sustituido por CLD en los siguientes porcentajes en masa: 0, $10,20,30$ y $60 \%$. Los resultados muestran que sustituciones de cemento por CLD de hasta el $10 \%$ en masa no alteran el comportamiento frente a la corrosión de los morteros al compararlos con los morteros libres de CLD (morteros control: $0 \%$ de sustitución de cemento por CLD). Se presentan también los datos para intervalos de sustitución más altos. Desde el punto de vista mecánico, la CLD muestra una moderada actividad puzolánica, obteniéndose el mejor comportamiento cuando el porcentaje de sustitución de CLD por cemento fue del $10 \%$ y la mezcla fue formulada con una relación agua/(conglomerante: CP + CLD) (a/c) de 0,5.

Palabras clave: reutilización de residuos, Puzolana, propiedades mecánicas, corrosión, durabilidad.

\section{SUMMARY}

The article describes a study conducted to determine corrosion in reinforcement embedded in Portland cement (PC) mortars with different percentages of sewage sludge ash (SSA) admixtures. The polarization resistance technique was used to determine the steel corrosion rate $\left(I_{\text {corr }}\right)$ in the test specimens. The samples were subjected to different environmental conditions and aggressive agents: $100 \%$ relative humidity $(\mathrm{RH})$, accelerated carbonation at $70 \% \mathrm{RH}$ and seawater immersion. Portland cement was partially substituted for SSA in the mixes at rates of $0,10,20,30$ and $60 \%$ (by mass) to make the different mortars. The results show that where cement was replaced by SSA at rates of up to $10 \%$ by mass, mortar corrosion performance was comparable to the behaviour observed in SSA-free mortars (control mortar: $0 \%$ SSA). Data for higher rates are also shown. From the mechanical standpoint, SSA exhibited moderate pozzolanic activity and the best performance when SSA was added at a rate of $10 \%$ to mixes with a water/(binder: $P C+S S A)(w / b)$ ratio of 0.5 .

Keywords: waste recycling, pozzolan, mechanical strength, corrosion, durability.

(*) Dpto. Construcciones Arquitectónicas. Universidad de Alicante, Alicante (España).

(**) Dpto. Ing. de la Construcción, Obras Públicas e Infr. Urb. Univ. Alicante (España).

(***) GIQUIMA. Dpto. Ing. de la Construcción y Proyectos de Ingeniería Civil. UPV, Valencia (España). 


\section{INTRODUCCIÓN}

El lodo de depuradora es un subproducto de las plantas de tratamiento de aguas residuales urbanas. El lodo está siendo usado como fertilizante en la agricultura para mejorar las propiedades de los terrenos de cultivo. Actualmente, se están estudiando usos alternativos de los lodos. La integración de estos productos en la industria de la construcción es uno de ellos.

Como resultado de la incineración de los lodos de depuradora, mediante la cual los compuestos orgánicos son descompuestos, se obtiene la ceniza de lodo de depuradora (CLD) con un volumen de sólo el $10 \%$ del original. La CLD puede ser usada en la fabricación de ladrillos (13), como árido fino en morteros (4) en la preparación de áridos sintéticos (5) o en pavimentos asfálticos (6). Una de las aplicaciones de mayor interés es como mezcla mineral en morteros y hormigones para uso en construcción (7-13).

El uso de CLD en el hormigón aporta patentes ventajas tanto desde el punto de vista económico como ecológico: la incorporación de CLD al hormigón implica, por un lado, la reducción de materias primas al ser reemplazadas por un producto de "coste-cero" (e.g. cemento, árido fino, filler) y, por otro lado, la optimización de esfuerzos en la gestión de residuos. Además, estudios previos $(9,10,13)$ demuestran muy buen comportamiento con respecto a las propiedades mecánicas de los materiales cementicios que contienen CLD: mejora en la resistencia a compresión desarrollada por los morteros de cemento Portland y estabilidad de volumen de las mezclas (10). Sin embargo, no se han encontrado estudios sobre la influencia del uso de CLD en el proceso de corrosión de las armaduras del hormigón armado. El comportamiento de la CLD en el hormigón es muy importante debido a la presencia de diferentes sales en su composición (principalmente cloruros y sulfatos adsorbidos o precipitados en el lodo de depuradora) que podrían causar la corrosión de las armaduras embebidas en él. Por tanto, el principal objetivo de este trabajo es proporcionar datos científicos sobre la cinética del proceso de corrosión de las armaduras de acero embebidas en morteros de cemento Portland que contienen CLD para evaluar la influencia de su cierta salinidad. Además se han estudiado diferentes porcentajes de sustitución de cemento por CLD con el objeto de hacer los resultados más interesantes desde el punto de vista económico.

Por todo ello, se ha estudiado el comportamiento de morteros, fabricados con distintos porcentajes de sustitución de cemento por CLD, al ser sometidos a diferentes condiciones agresivas con el objetivo de caracterizar su durabilidad en base a los valores de intensidad de corrosión ( $\mathrm{I}_{\text {corr }}$ ) registrados en las armaduras embebidas en los mismos.

\section{INTRODUCTION}

Sewage sludge, an urban waste water treatment plant by-product, is presently used as a fertilizer to enhance the properties of farm soil. But alternative uses of sludge are currently under study, including, among others, re-cycling in the construction industry.

On incineration and the concomitant elimination of the organic components in sewage sludge, the material is reduced to only around $10 \%$ of its original volume. The resulting ash, SSA, can then be used in brick manufacture (1-3), as fine aggregate in mortars (4), in the preparation of synthetic aggregate (5) or in bitumen for paving (6). One of the most promising applications is as a mineral admixture in construction mortar and concrete (7-13).

The use of SSA in concrete entails both ecological and economic benefits: for on the one hand this "zero-cost" product replaces other raw materials such as cement, fine aggregate or filler, and on the other its removal for re-use enhances waste management. Moreover, cementitious materials containing SSA have been reported to perform well in terms of mechanical properties $(9,10$, 13), with gains in compressive strength with respect to Portland cement mortars and good volume stability (10). And yet no studies have been found on the effect of this mineral admixture on concrete reinforcement corrosion. SSA behaviour in concrete in this regard is of particular importance, for its salt content (primarily chlorides and sulphates adsorbed on or precipitated in sewage sludge) might trigger the corrosion of reinforcing steel embedded in concrete. The chief aim of this study, therefore, was to furnish scientific data on the corrosion kinetics of steel bars embedded in PC mortars containing SSA to evaluate the possible influence of such salinity. At the same time, mixes with different proportions of SSA and $P C$ were analyzed to identify the most economically promising formulation.

The approach adopted to achieve these aims was to study the performance of mortars different substitution levels of cement by SSA under different aggressive conditions to determine reinforced mortar durability in terms of steel corrosion rates ( $\left.I_{\text {corr }}\right)$. 


\section{PROGRAMA EXPERIMENTAL}

\subsection{Materiales}

Para la realización de este estudio se han utilizado los siguientes materiales: cemento Portland CEM I 52.5 (CP) y arena silícea normalizada cumpliendo la norma europea UNE-EN 196-1 (14). La CLD utilizada procede de la planta incineradora de los lodos de depuradora de aguas urbanas residuales de Pinedo (Valencia). La composición química de la CLD se resume en la Tabla 1 . Las fases cristalinas principales determinadas mediante DRX han sido: $\gamma$-sulfato de calcio, cuarzo, magnetita, calcita e hidroxilapatito. Como fases cristalinas minoritarias se han detectado corindón, yeso y óxido de calcio. La ceniza es un polvo finamente dividido de color pardo, con un diámetro de partícula medio de $33 \mu \mathrm{m}$ (medido mediante difracción láser). La Figura 1 muestra la distribución de tamaños de partícula de la ceniza. La Figura 2 muestra las imágenes de microscopía electrónica de la ceniza. En ellas se observa la forma irregular de las partículas, así como la rugosidad de su superficie. El análisis químico de la ceniza ha revelado un contenido de sales solubles relativamente alto. De hecho, a $20^{\circ} \mathrm{C}$, para una suspensión acuosa de ceniza (10 g CLD/100 g agua desionizada) se ha obtenido un valor de conductividad eléctrica de $9,57 \mathrm{mS} / \mathrm{cm}$, un $\mathrm{pH}$ de 10,5 y un contenido de sales solubles en la fracción acuosa de $45 \mathrm{mg} / \mathrm{g}$ CLD (cloruros: 7,8 mg/g CLD y sulfatos: $37,2 \mathrm{mg} / \mathrm{g}$ CLD). Estos resultados podrían ser una factor determinante, especialmente desde el punto

\section{EXPERIMENTAL}

\subsection{Materials}

The following materials were used for this study: Portland cement type CEM-I 52.5 (PC) and CEN UNE-EN 196-1-compliant silica sand (14). SSA was supplied by the Pineda waste water treatment plant in the Spanish province of Valencia. The chemical composition of SSA is summarized in Table 1. The main crystalline phases determined with $X$-ray diffraction techniques were: $\gamma$-calcium sulphate, quartz, magnetite, calcite and hydroxylapatite. Corundum, gypsum and lime were also detected as minor or trace crystalline phases. The ash particles, forming a fine brownish powder, had a mean diameter of $33 \mu \mathrm{m}$ (measured by laser diffraction). The SSA particle size distribution is given in Figure 1. As the micrographs in Figure 2 show, the particles are irregularly shaped and their surface is rough. Chemical analysis revealed that the ash has a relatively high soluble salt content. At $20^{\circ} \mathrm{C}$, aqueous ash suspension ( $10 \mathrm{~g} \mathrm{SSA} / 100 \mathrm{~g}$ of deionised water) conductivity was $9.57 \mathrm{mS} / \mathrm{cm}$, its $\mathrm{pH}$ was 10.5 and the soluble salt content in the aqueous fraction was $45 \mathrm{mg} / \mathrm{g}$ SSA (chlorides: $7.8 \mathrm{mg} / \mathrm{g}$ SSA and sulphates: $37.2 \mathrm{mg} / \mathrm{g} \mathrm{SSA}$ ). Since salt content may be a determinant, particularly with respect to steel corrosion, the ash was mixed with deionised water to prepare a further series of specimens. The suspension was stirred for 10 minutes and then let stand for 15, after which the liquid phase was poured off. The wet ash was then dried in an

Tabla 1. Composición química de la ceniza de lodo de depuradora (CLD)

Table 1. Chemical composition of sewage sludge ash (SSA)

\begin{tabular}{|c|c|c|c|c|c|c|c|c|c|}
\hline$\%$ & $\begin{array}{l}\text { Pérdida al fuego } \\
\text { Loss on ignition }\end{array}$ & $\begin{array}{c}\text { Humedad } \\
\text { Moisture } \\
\end{array}$ & $\mathrm{CaO}$ & $\mathrm{SiO}_{2}$ & $\mathbf{A l}_{2} \mathbf{O}_{3}$ & $\mathrm{SO}_{3}$ & $\mathrm{Fe}_{2} \mathrm{O}_{3}$ & $\mathbf{P}_{2} \mathbf{O}_{5}$ & MgO \\
\hline $\begin{array}{l}\text { CLD } \\
\text { SSA }\end{array}$ & 5.1 & 0.5 & 31.3 & 20.8 & 14.9 & 12.4 & 7.4 & 6.7 & 2.6 \\
\hline
\end{tabular}

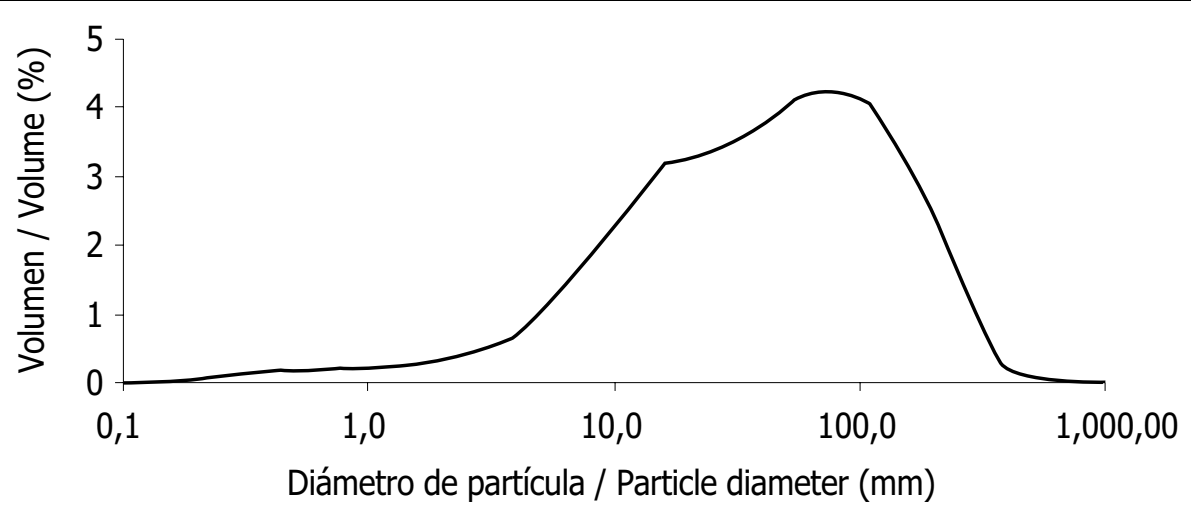

Figura 1. Distribución de tamaño de partícula de la CLD.

Figure 1. Particle size distribution of SSA. 

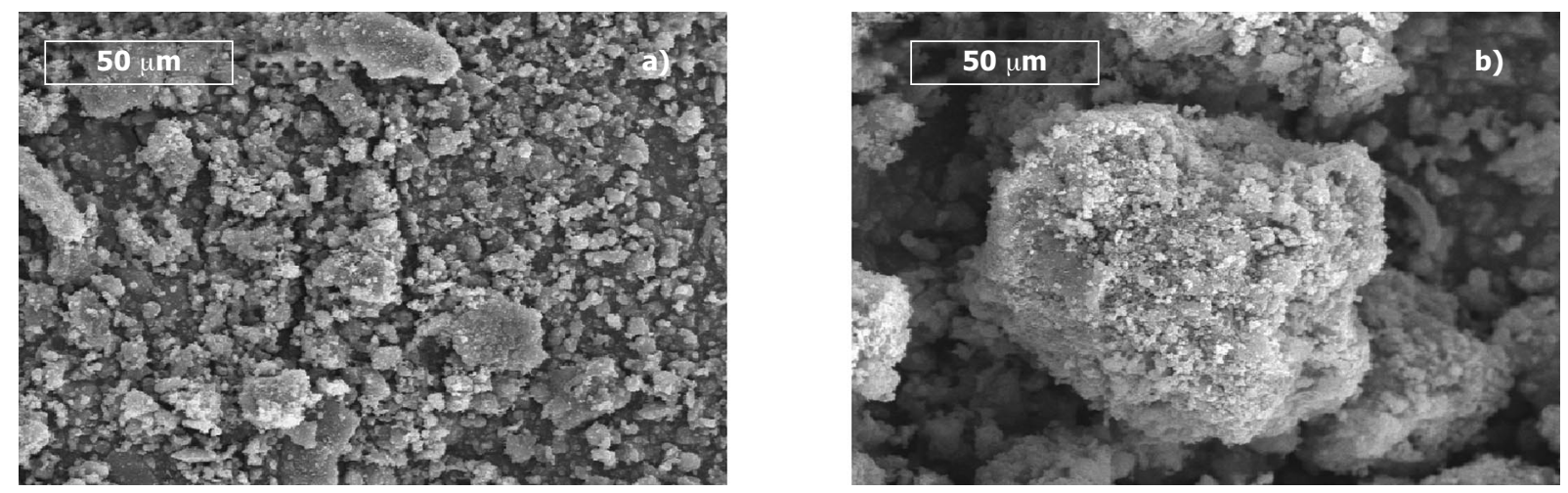

Figura 2. Imágenes de microscopía electrónica de la CLD: a) x500; b) ×2.000.

Figure 2. SEM micrographs of SSA: a) x500; b) x2,000.

de vista de la corrosión de las armaduras. Por esta razón, se ha preparado una muestra de ceniza adicional mezclando CLD con agua desionizada. Transcurridos diez minutos de agitación, se ha dejado reposar la suspensión durante quince minutos y finalmente se ha eliminado la fase líquida. La ceniza húmeda se ha secado en estufa a $105{ }^{\circ} \mathrm{C}$ hasta peso constante. Con este proceso, se ha eliminado la mayoría de las sales solubles y, en consecuencia, se ha reducido su efecto sobre el proceso de corrosión.

\subsection{Preparación de las muestras para las medidas de $\mathbf{I}_{\text {corr }}$}

Se han fabricado probetas prismáticas de morteros de dimensiones $80 \times 55 \times 20 \mathrm{~mm}$ con relación arena/(conglomerante: $C P+C L D) 3: 1$, relación a/c 0,5 y 0,7 y sustitución parcial de cemento por CLD en los siguientes porcentajes en masa: 0 (mortero control), 10, 20, 30 y $60 \%$. Cada probeta contiene dos electrodos cilíndricos de $8 \mathrm{~mm}$ de diámetro de acero al carbono y un contraelectrodo de grafito en el medio. El espesor de recubrimiento resultante es de $6 \mathrm{~mm}$. La Figura 3 muestra un esquema de las probetas utilizadas para las medidas de corrosión. El área expuesta del acero ha sido de 16,3 $\mathrm{cm}^{2}$. En cada probeta se ha medido el valor de $\mathrm{I}_{\text {corr }}$ para cada electrodo de acero y se ha tomado como resultado para la misma el valor medio de ambos. La duración del proceso de medida ha sido el tiempo suficiente hasta conseguir valores de $\mathrm{I}_{\text {corr }}$ estables.

Una vez curadas las probetas durante 28 días en cámara húmeda $\left(100 \% \mathrm{HR}\right.$ y a $\left.20^{\circ} \mathrm{C}\right)$, se han sometido a diferentes condiciones ambientales: atmósfera con humedad relativa $100 \%(100 \% \mathrm{HR})$, inmersión en agua de mar filtrada y proceso de carbonatación acelerada (con $\mathrm{CO}_{2}$ puro y $70 \%$ de HR). Todos estos ensayos se han realizado a una temperatura de $20^{\circ} \mathrm{C}$. oven at $105^{\circ} \mathrm{C}$ to a constant weight. This procedure eliminated most of the soluble salts and hence their potential corrosive effect on the steel.

\subsection{Specimen preparation for $I_{\text {corr }}$ measurements}

Prismatic mortar specimens measuring $80 \times 55 \times 20 \mathrm{~mm}$ were made from mixes with a sand /(binder: $P C+S S A)$ ratio of $3: 1$ and $w / b$ ratios of 0.5 and 0.7 , substituting SSA for cement at rates of 0 (control mortar), 10, 20, 30 and $60 \%$ by mass. Each specimen contained two $8-\mathrm{mm}$ diameter carbon steel cylindrical electrodes and one graphite counter-electrode. This left room for a 6- $\mathrm{mm}$ cover. Figure 3 contains a sketch of the specimens used for corrosion measurements. An area of $16.3 \mathrm{~cm}^{2}$ of steel was exposed. The average of the $I_{\text {corr }}$ values measured in the two electrodes in each specimen was taken as the value for the specimen in question. Measurements were taken until the $I_{\text {corr }}$ values stabilized.

After 28-day curing in a moist closet (100\% RH, $\left.20^{\circ} \mathrm{C}\right)$, the specimens were subjected to different environmental conditions: $100 \% \mathrm{RH}$, seawater immersion and accelerated carbonation (at $70 \% \mathrm{RH}$ in a pure $\mathrm{CO}_{2}$ atmosphere). All tests were conducted at $20^{\circ} \mathrm{C}$. 

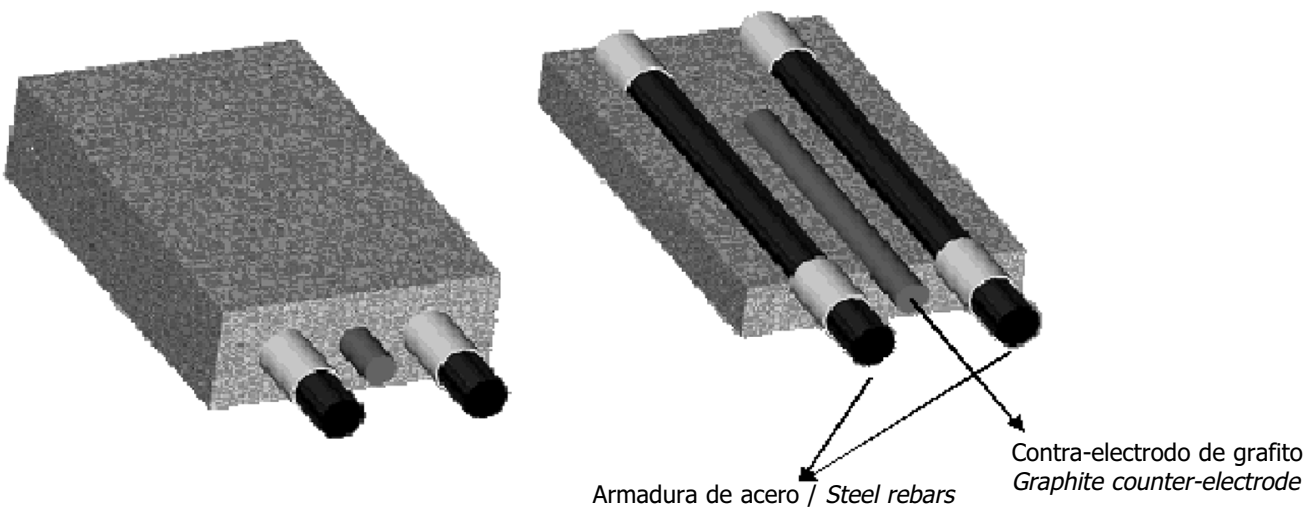

Figura 3. Esquema de las probetas utilizadas para las medidas de corrosión.

Figure 3. Sketch of the specimen for corrosion measurements.

\subsection{Técnica de medida de la corrosión}

La técnica electroquímica usada para medir la velocidad de corrosión instantánea, $\mathrm{I}_{\text {corr }}$ ha sido la técnica de la Resistencia a la Polarización, a través de la bien conocida fórmula de Geary y Stern (15) $I_{\text {corr }}=B / R_{p}$. $I_{\text {corr }}$ se ha calculado considerando $B=26 \mathrm{mV}$ para acero corroído o $52 \mathrm{mV}$ para acero pasivado (16). Durante todo el tiempo del experimento se ha medido periódicamente $R_{p}$ y el potencial de corrosión $\left(\mathrm{E}_{\text {corr }}\right)$. Al final del mismo, se ha determinado para cada electrodo la pérdida de peso (pérdida gravimétrica). Todos los valores de potencial están referidos al electrodo de calomelanos saturado (ECS). Se ha usado un Potenciostato-Galvanostato 362 EG\&G. Los valores de $\mathrm{I}_{\text {corr }}$ han sido calculados como el valor medio entre cuatro medidas (dos probetas, dos electrodos cada una). La pérdida de peso electroquímica estimada de la integración de las curvas de $\mathrm{I}_{\text {corr }}$ en función del tiempo ha sido comparada con la pérdida gravimétrica correspondiente (obtenida directamente mediante pesada). La buena concordancia obtenida entre ambas valida el valor de B empleado.

\subsection{Estudio de la resistencia mecánica}

La resistencia mecánica de los morteros fue obtenida usando probetas prismáticas de mortero de $40 \times 40 \times$ $160 \mathrm{~mm}$ según los requerimientos de la norma EN-1961 (14). Las distintas formulaciones de los morteros ensayados han sido las mismas que las realizadas para los estudios de corrosión. Para determinar la evolución de las resistencias mecánicas a flexión y compresión con el tiempo de curado bajo agua fueron ensayadas a las siguientes edades de curado: 7, 28 y 90 días. La porosidad total de las muestras ha sido medida a los 90 días. Se ha utilizado la siguiente fórmula para calcularla: Poro$\operatorname{sidad}(\%)=\left(P_{\text {sat }}-P_{\text {seco }}\right) /\left(P_{\text {sat }}-P_{B H}\right)$, siendo $P_{\text {sat }}$ $=$ Peso de la muestra saturada en agua (mediante bomba

\subsection{Corrosion measurement}

The polarization resistance technique was used to measure the instantaneous corrosion rate, $I_{\text {corr }}$ applying the well known Stern and Geary formula (15), $I_{\text {corr }}=B / R p$, and assuming $B$ values of $26 \mathrm{mV}$ for corroding steel and $52 \mathrm{mV}$ for passive reinforcement (16). $R p$ and the corrosion potential $\left(E_{\text {corr }}\right)$ were measured periodically throughout the experiment and weight loss (gravimetric loss) was found for each electrode at the end of the trials. The saturated calomel electrode (SCE) was used as the standard reference in all measurements of potential, which were taken with a Galvanostat $362 \mathrm{EG \& G}$ potentiostat. $I_{\text {corr }}$ data were calculated as the average of four values (two specimens with two electrodes each). The electrochemical weight loss estimated by integrating the $I_{\text {corr }} v s$ time curves was compared to the respective gravimetric weight loss obtained by direct measurements. The good correlation between the two series of weight loss values validated the $B$ values employed.

\subsection{Mechanical strength}

The mechanical strength of the mortars prepared was tested on prismatic $40 \times 40 \times 160 \mathrm{~mm}$ specimens as described in European standard EN-196-1 (14). The mortar mixes were the same as used for the corrosion studies. Mechanical (flexural and compressive) strength was evaluated in submerged specimens, tested at the ages of 7 , 28 and 90 days. Specimens were analyzed for total porosity after 90 days. The uptake percentage was found with the following formula: Porosity (\%) $=($ Wsat - Wdry) / (Wsat - Wsubm ) where Wsat = water-saturated weight of the specimens ; Wdry = dry weight of the specimens after heating to $105{ }^{\circ} \mathrm{C}$ and subsequent cooling in a chemical dessicator; and Wsubm = weight 
de vacío); $\mathrm{P}_{\text {seco }}=$ Peso de la muestra secada en estufa a $105^{\circ} \mathrm{C}$ y posteriormente enfriada en desecador quími$\mathrm{co} ; \mathrm{P}_{\mathrm{BH}}=$ Peso de la muestra en la balanza hidrostática (saturada y sumergida).

\section{RESULTADOS Y DISCUSIÓN}

\subsection{Estudios de resistencia y porosidad}

Los valores de evolución de la resistencia mecánica y de porosidad se resumen en la Tabla 2 . Con respecto a la resistencia a flexión, se puede observar que los valores más altos han sido obtenidos para los morteros control $\left(\mathrm{Rf}_{\mathrm{o}}\right)$. Se ha observado un descenso en los valores de resistencia a flexión $\left(\mathrm{Rf}_{\mathrm{i}}\right)$ en todos los morteros que contienen CLD conforme aumenta el porcentaje de sustitución de CP por CLD. La Figura 4 muestra la relación $\mathrm{Rf}_{\mathrm{i}} / \mathrm{Rf}_{\mathrm{O}}$ en función del tiempo de curado. En general, esta of the sample on a hydrostatic scale (saturated and submerged).

\section{RESULTS AND DISCUSSION}

\subsection{Strength and porosity}

Strength and porosity data for all the specimens prepared are summarized in Table 2. Flexural strength values were highest for the control mortars and declined with increasing proportions of SSA (in place of PC). Figure 4 shows the test specimen/control flexural strength ratio $\left(R f_{j} / R f_{0}\right)$ at different curing times. As a general rule, the $R f_{j} / R f_{0}$ ratio for a given curing age was nearly the same as the value of the cement content ratio $C_{i} / C_{0}$, where $C_{i}$ is the PC content for SSA mortars and $C_{0}$ the content for

Tabla 2 / Table 2

Valores de resistencia a flexión, compresión y porosidad total (en volumen)

Flexural and compressive strengths and total porosity values (in volume)

\begin{tabular}{|c|c|c|c|c|c|c|c|c|c|}
\hline \multirow[t]{2}{*}{$\begin{array}{l}\text { Relación a/c } \\
\text { w/b Ratio }\end{array}$} & \multirow[t]{2}{*}{$\begin{array}{c}\% \text { CLD } \\
\text { SSA }\end{array}$} & \multicolumn{3}{|c|}{$\begin{array}{c}\text { Resistencia Flexión } \\
\text { Flexural Strength } \\
\text { (Rf, MPa) }\end{array}$} & \multicolumn{3}{|c|}{$\begin{array}{c}\text { Resistencia Compresión } \\
\text { Compressive Strength } \\
\text { (Rc, MPa) }\end{array}$} & \multirow[t]{2}{*}{$\begin{array}{c}\text { Porosidad Total } \\
\text { Total Porosity } \\
\text { (\%) }\end{array}$} & \multirow[t]{2}{*}{$c_{i} / c_{o}$} \\
\hline & & $7 \mathrm{~d}$ & $28 \mathrm{~d}$ & $90 \mathrm{~d}$ & $7 \mathrm{~d}$ & $28 \mathrm{~d}$ & $90 \mathrm{~d}$ & & \\
\hline \multirow{5}{*}{0.5} & 0 & 7.7 & 9.1 & 9.5 & 49.5 & 62.0 & 70.0 & 17.59 & 1 \\
\hline & 10 & 7.3 & 8.3 & 8.7 & 49.5 & 57.5 & 67.0 & 18.89 & 0.9 \\
\hline & 20 & 5.3 & 7.3 & 7.8 & 39.0 & 50.0 & 58.0 & 20.84 & 0.8 \\
\hline & 30 & 4.2 & 6.8 & 7.3 & 25.5 & 42.0 & 48.0 & 21.39 & 0.7 \\
\hline & 60 & 0.3 & 0.7 & 0.9 & 5.0 & 6.0 & 9.5 & 32.12 & 0.4 \\
\hline \multirow{5}{*}{0.7} & 0 & 6.3 & 7.7 & 8.4 & 31.5 & 41.5 & 48.5 & 21.58 & 1 \\
\hline & 10 & 5.7 & 6.9 & 7.6 & 28.0 & 35.5 & 45.0 & 23.78 & 0.9 \\
\hline & 20 & 3.6 & 6.0 & 6.6 & 17.5 & 29.5 & 35.0 & 25.53 & 0.8 \\
\hline & 30 & 2.9 & 5.1 & 5.8 & 12.5 & 23.5 & 31.0 & 26.76 & 0.7 \\
\hline & 60 & 2.3 & 3.3 & 4.1 & 9.0 & 13.0 & 19.5 & 29.42 & 0.4 \\
\hline
\end{tabular}

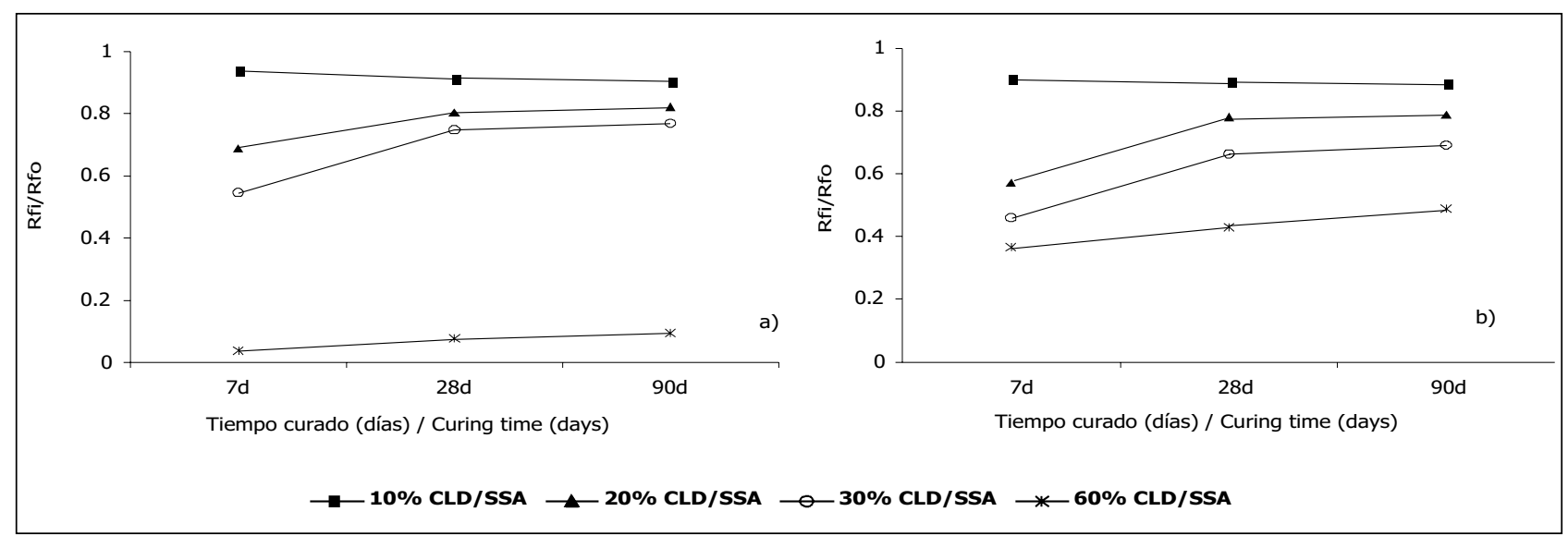

Figura 4. Relación $\mathrm{Rf}_{\mathrm{i}} / \mathrm{Rf}_{\mathrm{o}}$ frente al tiempo de curado: a) relación $\mathrm{a} / \mathrm{c}=0,5 ; \mathrm{b}$ ) relación $\mathrm{a} / \mathrm{c}=0,7$.

Figure 4. $R f_{j} / R f_{o}$ ratios versus curing time: $a$ ) $w / b$ ratio $\left.=0.5 ; b\right) w / b$ ratio $=0.7$. 
relación, para una edad de curado dada, es cercana a la relación del contenido de cemento relativo $\mathrm{C}_{\mathrm{i}} / \mathrm{C}_{\mathrm{o}}$ donde $\mathrm{C}_{\mathrm{i}}$ es el contenido de cemento Portland en los morteros que contienen CLD y $\mathrm{C}_{0}$ en los morteros control. Este comportamiento no ha sido observado en las probetas que contienen $60 \%$ de CLD y relación a/c de 0,5 , en las cuales los valores de $\mathrm{Rf}_{\mathrm{i}}$ han sido menores que $1 \mathrm{MPa}$, lo que indica problemas con la porosidad y homogeneidad de la muestra. De hecho, la porosidad obtenida en estas muestras ha sido más de un $50 \%$ más alta que la obtenida por las otras muestras estudiadas. Los valores de resistencia a compresión Rc para las muestras fabricadas con $60 \%$ de CLD, debido a la difícil compactación, han sido inferiores a $10 \mathrm{MPa}$.

Se han encontrado tendencias similares al comportamiento en flexión para la resistencia a compresión desarrollada por los morteros estudiados. La Figura 5 muestra la relación $R c_{i} / R c_{0}$ frente al tiempo de curado, siendo $R c_{i}$ la resistencia a compresión para los morteros que contienen CLD y $\mathrm{Rc}_{0}$ para el mortero control, para una edad de curado determinada. Los morteros fabricados con un $10 \%$ de CLD proporcionan los mejores valores, observándose cómo la resistencia a compresión disminuye conforme aumenta el porcentaje de CLD. En general, los valores de la relación $\mathrm{Rc}_{\mathrm{i}} / \mathrm{Rc}_{\mathrm{o}}$ han sido cercanos a la relación de contenido de cemento $C_{i} / C_{0}$, indicando una moderada actividad puzolánica de las cenizas. La actividad puzolánica de la CLD ha sido estudiada desde el punto de vista de la fijación de cal en trabajos previos (17). Además, se debe tener en cuenta que para los morteros fabricados con CLD, la relación a/c ha sido la misma que para los morteros control, aunque para los morteros con CLD la relación agua/CP ha sido más alta, y consecuentemente, su resistencia a compresión debería ser notablemente más baja que la obtenida por el mortero control. Únicamente la relación $\mathrm{Rc}_{\mathrm{i}} / \mathrm{Rc}_{\mathrm{o}}$ para los morteros con un $10 \%$ de CLD y relación a/c $=0,5$ proporciona valores claramente más altos que $C_{i} / C_{0}$, resultado que indica que desde el punto de vista de las propiedades mecánicas éste es el mejor porcentaje de sustitución. Otro hecho interesante es el incremento de la relación $\mathrm{Rc}_{\mathrm{i}} / \mathrm{Rc}_{\mathrm{o}}$ con la edad de curado para cada formulación, lo que sugiere que la reacción puzolánica se ha estado desarrollando a lo largo del intervalo de edad de curado estudiado.

Finalmente, se ha observado, para las relaciones $a / c$ 0,5 y 0,7 estudiadas, un incremento de la porosidad total cuando la CLD se añade como material sustitutivo del cemento. Este comportamiento muestra que la presencia de CLD dificulta la compactación de la mezcla, debido a la demanda de agua que genera la CLD (11). Además, la rugosidad superficial de las partículas de CLD podría contribuir a este comportamiento. Los valores de porosidad total para las muestras fabricadas con relación a/c 0,7 han sido más grandes que los obtenidos con las fabricadas con relación control mortars. The exception was the specimens containing $60 \%$ SSA with a $w / b$ ratio of 0.5 , where the $R f_{i}$ values were lower than $1 \mathrm{MPa}$, a finding suggestive of porosity and homogeneity-related problems. Indeed, the porosity found for these specimens was over 50\% higher than in the other samples studied. Compressive strength values (Rc) for $60 \%$ SSA samples were also found to be very low due to difficult in compaction, with Rc values of under $10 \mathrm{MPa}$.

The trends for compressive strength were similar to the findings for flexural strength. Figure 5 shows the $R c_{j} / R c_{O}$ ratios, where $R c_{i}$ is the compressive strength for SSAcontaining mortars and $R c_{0}$ for the control mortars of the same age. The highest values were found for $10 \%$ SSA mortars, with Rc declining as the ash content rose. Generally speaking, $R c_{i} / R c_{o}$ values were close to $C_{i} / C_{O}$ ratios, inferring that the ash exhibits moderate pozzolanic activity, a question addressed in a previous study (17) in connection with lime fixation. Moreover, since the $w / b$ ratio was the same in the SSA and control mortars and the w/PC ratio therefore higher in the former, compressive strength would be expected to be substantially lower in the SSA specimens than in the control. Only the $10 \%$ SSA mortars with a $w / b$ ratio of 0.5 had clearly higher $R c_{i} / R c_{o}$ than $C_{j} / C_{O}$ values, denoting the greater suitability of this replacement percentage from the standpoint of mechanical properties. Another interesting finding is that the $R c_{j} / R c_{o}$ ratio grew with curing age in all mortars, from which it may be deduced that the pozzolanic reaction took place throughout the curing process.

Finally, the increase in total porosity with SSA content at $w / b$ ratios of 0.5 and 0.7 is an indication that the presence of SSA renders compaction more difficult, due to the higher water demand of ash-bearing mixes (11) as well, perhaps, as to rough SSA particle surfaces. As might be expected, total porosity values for specimens with a $w / b$ ratio of 0.7 were higher than in the respective samples with a ratio of 0.5 . Mortars containing $60 \%$ SSA were more readily consolidated when a higher proportion of water was used. Compaction was likewise 


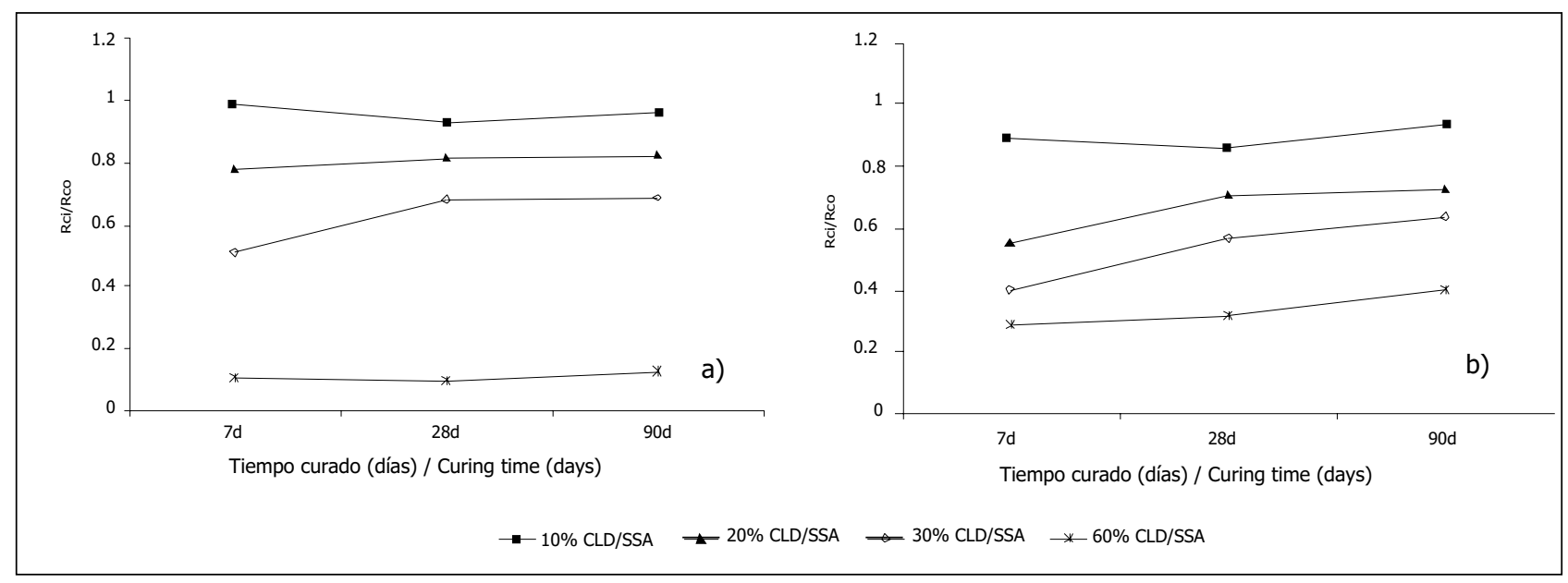

Figura 5. Relación $R c_{i} / R c_{0}$ frente al tiempo de curado: a) relación $\left.a / c=0,5 ; b\right)$ relación $a / c=0,7$. Figure 5. $R c_{i} / R c_{o}$ ratios versus curing time: $\left.a\right) w / b$ ratio $\left.=0.5 ; b\right) w / b$ ratio $=0.7$.

0,5 , tal y como era de esperar. Se puede destacar que para morteros fabricados con un $60 \%$ de CLD, se ha conseguido mejor compactación cuando mayor cantidad de agua se ha usado. Por otro lado, ha sido difícil obtener morteros bien compactados cuando se fabricaron con relación a/c 0,5 y porcentajes de sustitución de 30 y $60 \%$. En ambos casos, la trabajabilidad de la mezcla en estado fresco no ha sido demasiado buena.

\subsection{Estudios de corrosión}

\subsubsection{Estudios de corrosión en probetas sometidas} a $100 \% \mathrm{HR}$

La Figura 6 muestra la evolución de $\mathrm{I}_{\text {corr }}$ en los morteros fabricados con diferentes porcentajes de sustitución de cemento por CLD: 0, 10, 20, 30 y 60\%. Las probetas han sido almacenadas en una atmósfera saturada de agua (100\% HR). En esta Figura, la banda marcada entre 0,1$0,2 \mu \mathrm{A} / \mathrm{cm}^{2}$ señala el umbral de corrosión: debajo de ella la corrosión se considera despreciable siendo alta en la zona por encima de la misma, lo que reduce la vida en servicio estructural (18). Las medidas de $\mathrm{I}_{\text {corr }}$ se empezaron a tomar inmediatamente después del desmoldeo de las probetas y continuaron tomándose periódicamente hasta el final de las experiencias.

Para todas las muestras fabricadas con relación a/c 0,7 (Figura 6 a) y durante el intervalo de tiempo experimental estudiado, los valores de $\mathrm{I}_{\text {corr }}$ más altos han sido los obtenidos durante el periodo inicial. Los valores observados han sido de $0,2 \mu \mathrm{A} / \mathrm{cm}^{2}$ para los morteros control y de $0,28,0,09,0,08$ y $0,17 \mu \mathrm{A} / \mathrm{cm}^{2}$ para las muestras con porcentajes en masa de sustitución de cemento por CLD de $10,20,30$ y $60 \%$ respectivamente.

A los pocos días, se ha observado una reducción continua de los valores de $\mathrm{I}_{\text {corr, }}$ excepto para las muestras con $60 \%$ difficult in mortars with a $w / b$ ratio of 0.5 and containing 30 or $60 \%$ SSA. Mix workability was relatively poor in these cases.

\subsection{Corrosion study}

\subsubsection{Corrosion study in specimens subjected at $100 \% \mathrm{RH}$}

Figure 6 shows the $I_{\text {corr }}$ values vs time in Portland cement mortars with different percentages of SSA: 0,10 , 20,30 and $60 \%$ ( $\%$ of cement mass replaced by SSA). The specimens were stored in a water saturated $(100 \%$ $\mathrm{RH}$ ) atmosphere. The band at $0.1-0.2 \mu \mathrm{A} / \mathrm{cm}^{2}$ in this Figure marks the corrosion threshold: corrosion is regarded to negligible below the band, whereas levels above it can reduce the service life of the structure (18). $\mathrm{I}_{\text {corr }}$ measurements were begun immediately after specimen demoulding and taken daily thereafter.

For all samples with a $w / b$ ratio of 0.7 , the highest $I_{\text {corr }}$ values were recorded during the initial period (Figure 6a). The values obtained were $0.2 \mu \mathrm{A} / \mathrm{cm}^{2}$ for control mortars and $0.28,0.09,0.08$ and $0.17 \mu A / \mathrm{cm}^{2}$ for 10 , 20, 30 and $60 \%$ SSA specimens, respectively.

$I_{\text {corr }}$ values were observed to decline steadily after a few days in all but the 60\% SSA specimens. After about 20 
de CLD. Después de un periodo de alrededor de 20 días, los niveles de corrosión alcanzan valores estables del orden de $0,02 \mu \mathrm{A} / \mathrm{cm}^{2}$ para las muestras con 10,20 y $30 \%$ de CLD y de 0,012 $\mu \mathrm{A} / \mathrm{cm}^{2}$ para el mortero control. Sólo se han registrado niveles de corrosión activos en las muestras fabricadas con un $60 \%$ de CLD. Es interesante resaltar que todas las muestras con 10,20 y $30 \%$ de CLD han mostrado valores por debajo del umbral de corrosión. Los valores elevados de $\mathrm{I}_{\text {corr }}$ obtenidos con las muestras fabricadas con un $60 \%$ de CLD son coherentes con la elevada porosidad registrada en estas muestras y el contenido salino total, debido a la elevada cantidad de CLD en la mezcla.

Mediante la reducción de la relación a/c a 0,5 (Figura 6 b), sólo se ha detectado una pequeña mejora en el comportamiento ante la corrosión en las muestras fabricadas con 0 , 10 y $20 \%$ de CLD, obteniéndose valores similares para todas ellas. En cualquier caso, en todas ellas los aceros se mantienen en estado pasivo. Por el contrario, los valores de velocidad de corrosión registrados para las muestras con 30 y $60 \%$ de CLD han sido más altos que los obtenidos con las probetas fabricadas con relación $\mathrm{a} / \mathrm{c}=0,7$. Estos resultados pueden ser explicados por la escasa trabajabilidad de las mezclas que contienen altos porcentajes de CLD, debido a la elevada demanda de agua de la ceniza.

A partir de los resultados obtenidos, se concluye que la sustitución de cemento Portland por CLD en el intervalo comprendido entre 0 y $20 \%$ no ha afectado al comportamiento frente a la corrosión de estos morteros almacenados en condiciones de $100 \%$ HR.

\subsubsection{Inmersión parcial en agua de mar}

Los valores de $\mathrm{I}_{\text {corr }}$ de las muestras sometidas a inmersión parcial en agua de mar se muestran en la Figura 7. Las muestras se disponen en recipientes en los que el agua de days corrosion levels flattened at around $0.02 \mu \mathrm{A} / \mathrm{cm}^{2}$ for the 10, 20 and 30\% SSA samples and at $0.012 \mu \mathrm{A} / \mathrm{cm}^{2}$ for the control mortar. Active corrosion was recorded only in the $60 \%$ SSA specimens. None of the 0, 10, 20 or $30 \%$ SSA specimens crossed the corrosion threshold. The high $I_{\text {corr }}$ values for $60 \%$ SSA samples are consistent with the high porosity in these samples and their total saline content, both resulting from the large proportion of SSA in the mix.

A reduction of the $w / b$ ratio to 0.5 (Figure $6 \mathrm{~b}$ ) led to only a slight improvement in 0, 10 and 20\% SSA specimen corrosion performance, with similar $I_{\text {corr }}$ values recorded for all these samples. The reinforcement steel, moreover, remained passive in all cases. On the contrary, the corrosion rate values recorded for 30 and $60 \%$ SSA with a $w / b$ ratio of 0.5 were higher than for the specimens made with a ratio of 0.7 . The explanation is to be found in the poor workability of mixes with high proportions of SSA, due to the increased water demand.

It may be concluded on the grounds of the above results that replacing Portland cement with SSA in a range of 0 $20 \%$ had no effect on the corrosion performance or mortar stored at $100 \%$ RH.

\subsubsection{Partial seawater immersion}

The $I_{\text {corr }}$ values for the samples subjected to partial immersion in seawater are given in Figure 7. The specimens were nearly wholly immersed in seawater, as close

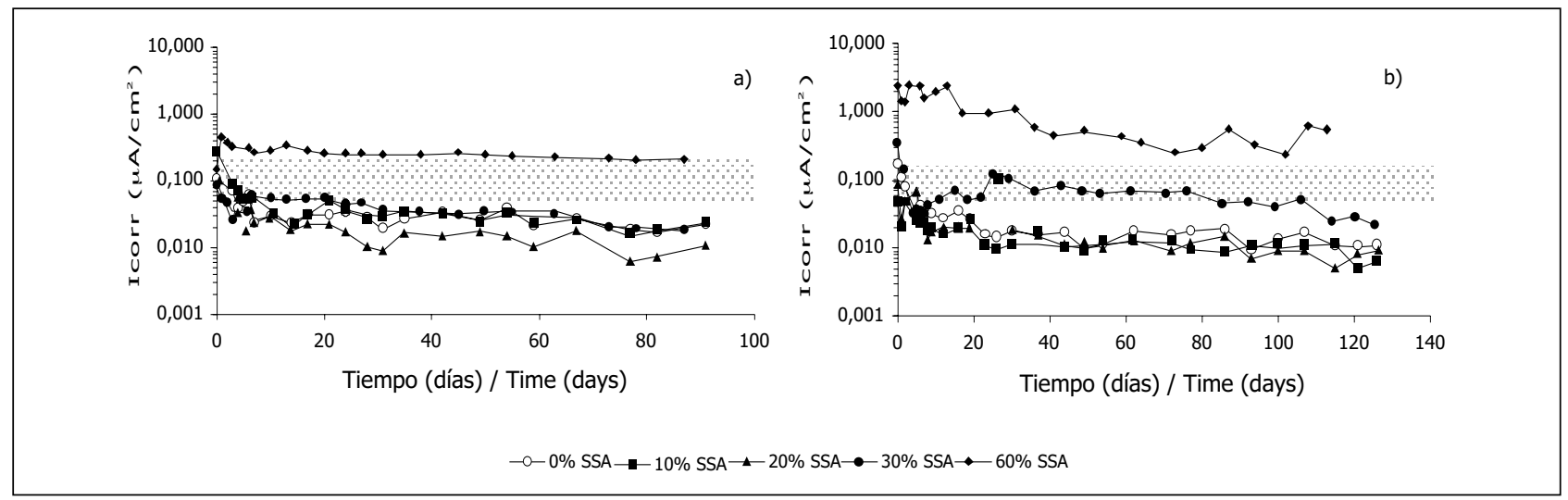

Figura 6. Evolución de los valores de $\mathrm{I}_{\text {corr }}$ de las armaduras de acero embebidas en probetas fabricadas con $0,10,20,30$ y $60 \%$ en masa de sustitución de cemento por CLD. 100\% HR. a) Relación a/c=0,7; b) Relación a/c=0,5.

Figure 6. Evolution of $I_{\text {corr }}$ in steel bars embedded in samples with 0, 10, 20, 30 and 60\% replacement of Portland cement mass by SSA. $100 \%$ RH. a) $w / b$ ratio $=0.7 ; b) w / b$ ratio $=0.5$. 


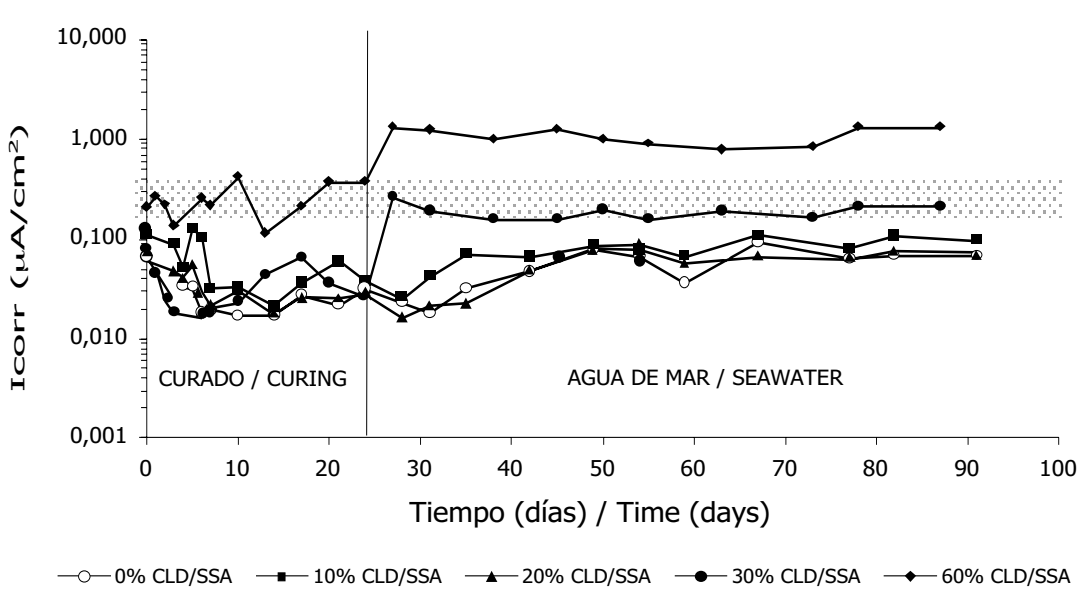

Figura 7. Evolución de los valores de $\mathrm{I}_{\text {corr }}$ de las armaduras de acero embebidas en probetas fabricadas con $0,10,20,30$ y $60 \%$ en masa de sustitución de cemento por CLD. Relación a/c =0,7 e inmersión parcial en agua de mar.

Figure 7. Evolution of $I_{\text {corr }}$ in steel bars embedded in samples with $0,10,20,30$ and $60 \%$ replacement of Portland cement mass by SSA and partially submerged in seawater. $w / b$ ratio $=0.7$.

mar recubre la práctica totalidad del mortero manteniéndose su nivel $1 \mathrm{~cm}$ por debajo de la parte superior de las probetas para evitar que los electrodos entren en contacto con ella. Los valores iniciales de $\mathrm{I}_{\text {corr }}$ se han obtenido dentro del intervalo $0,05-0,22 \mu \mathrm{A} / \mathrm{cm}^{2}$. Durante el periodo de curado de 28 días, en el cual las muestras se han conservado en cámara húmeda, los valores de $\mathrm{I}_{\text {corr }}$ han disminuido a valores comprendidos entre $0,02-0,07 \mu \mathrm{A} / \mathrm{cm}^{2}$, a excepción, de nuevo, de las probetas fabricadas con $60 \%$ de CLD. Es interesante resaltar que después de la inmersión parcial en agua de mar los valores de $\mathrm{I}_{\text {corr }}$ aumentan en todos los casos pero manteniéndose bajo el umbral de corrosión, obteniéndose valores similares para las probetas fabricadas con 0,10 y $20 \%$ CLD. También se debe destacar que los incrementos más altos experimentados en los valores de $\mathrm{I}_{\text {corr }}$ después de la inmersión en agua de mar han sido registrados para las probetas con más altos contenidos en CLD, aquéllas con valores de porosidad más altos y, por lo tanto, en las que los cloruros alcanzan más pronto la superficie de la armadura.

\subsubsection{Carbonatación acelerada}

Para estudiar el comportamiento frente a la corrosión en morteros en los que la alcalinidad ha sido neutralizada se ha sometido a las probetas a un proceso de carbonatación acelerada. Los resultados obtenidos se muestran en la Figura 8. Durante el periodo de curado, previo al proceso de carbonatación acelerada, los valores de $\mathrm{I}_{\text {corr }}$ alcanzaron valores estables comprendidos dentro del intervalo 0,007-0,03 $\mu \mathrm{A} / \mathrm{cm}^{2}$ en todos los casos, excepto, de nuevo, en las muestras fabricadas con $60 \%$ de CLD. En esas condiciones, las as possible to the top (within $1 \mathrm{~cm}$ ) without wetting the electrodes. The initial $I_{\text {corr }}$ values ranged from 0.05 to $0.22 \mu \mathrm{A} / \mathrm{cm}^{2}$. In the 28-day period in which the samples were stored in a water saturated atmosphere $(100 \% R H)$, the $I_{\text {corr }}$ values declined to $0.02-0.07 \mu A / \mathrm{cm}^{2}$ except, again, in the case of the $60 \%$ SSA specimens. The $I_{\text {corr }}$ values were very similar for the control and 10 and $20 \%$ SSA mortars and although they rose in all cases after partial immersion, they did not cross the corrosion threshold. The highest rises in $I_{\text {corr }}$ values after immersion were recorded for specimens with the highest SSA content, i.e., the specimens with the highest porosity and therefore the ones in which chloride ions could most readily access the surface of the steel.

\subsubsection{Accelerated carbonation}

Accelerated carbonation was performed to analyze the corrosion performance of mortars in which alkalinity had been neutralized. The results are shown in Figure 8. During the curing period prior to the $\mathrm{CO}_{2}$ attack, the $I_{\text {corr }}$ values had stabilized in a range of 0.007 to 0.03 $\mu A / \mathrm{cm}^{2}$ in all except the $60 \%$ SSA samples. The cured specimens were stored in a $\mathrm{CO}_{2}$ pure atmosphere at $70 \% \mathrm{RH}$. An abrupt increase in $I_{\text {corr }}$ was observed almost immediately, as would be expected during 
probetas se sometieron a una atmósfera de $\mathrm{CO}_{2}$ puro y $70 \%$ de HR. Inmediatamente después de empezar el periodo de carbonatación, se registró un brusco incremento de los valores de $I_{\text {corr }}$ para todas las muestras, como era de esperar cuando se neutraliza la capa de mortero de recubrimiento (la cual ha sido sólo de $6 \mathrm{~mm}$ de espesor). La velocidad de corrosión alcanzó valores estables, diferentes para cada uno de los distintos tipos de morteros estudiados, a lo largo del periodo durante el que se sometieron a carbonatación. Las muestras con 10\% de CLD han ofrecido los valores más pequeños $y$, a la vez, similares a los del mortero control. Los valores de $\mathrm{I}_{\text {corr }}$ aumentan paralelamente al contenido de CLD en el mortero. Una vez más, los valores más altos son los obtenidos con las muestras fabricadas con un $60 \%$ de CLD.

Una vez carbonatado totalmente el mortero, las probetas se almacenaron en una atmósfera con $100 \%$ de HR y se continuó el proceso de medida de la velocidad de corrosión. Las probetas, finalmente, alcanzaron valores estables y, de nuevo, las que mejor comportamiento frente a la corrosión presentaron han sido las fabricadas con $10 \%$ de CLD, ligeramente mejor que las del mortero control, aunque, en todos los casos, con valores en la zona de corrosión activa y superiores a $0,2 \mu \mathrm{A} / \mathrm{cm}^{2}$.

\subsubsection{Estudios usando la ceniza lavada}

Para reducir la concentración de sales solubles en la CLD, las cuales podrían ser un factor importante en los niveles de corrosión del acero, una muestra de CLD ha sido mortar cover (only $6 \mathrm{~mm}$ thick) neutralization. The corrosion rates stabilized during the carbonation process, albeit at different values depending on the specimen type. Values were lowest in the $10 \%$ SSA specimens, where they were similar to the control values, and rose with SSA content. The highest values were again recorded for the $60 \%$ SSA specimens.

After the mortar was fully carbonated, the specimens were stored in a $100 \% \mathrm{RH}$ atmosphere where $I_{\text {corr }}$ readings continued to be taken. Once a steady state was reached, the $10 \%$ SSA specimens again exhibited the best performance, even slightly better than the control, although all values were above the active corrosion threshold of $0.2 \mu \mathrm{A} / \mathrm{cm}^{2}$.

\subsubsection{Washed ash}

A sample of sewage sludge ash was washed with deionized water as described in 2.1 to reduce SSA soluble salt concentration, which may contribute substantially to steel

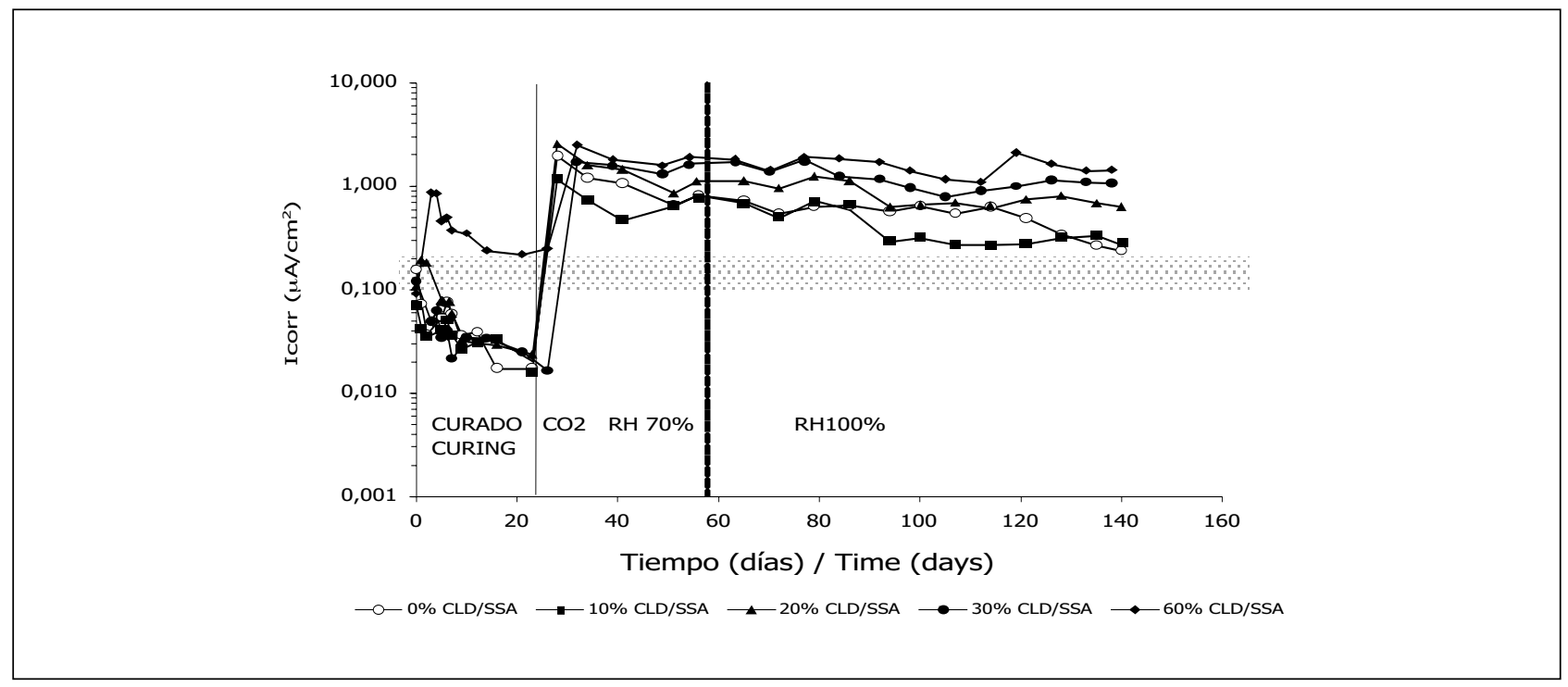

Figura 8. Evolución de los valores de Icorr de las armaduras de acero embebidas en probetas fabricadas con $0,10,20,30$ y $60 \%$ en masa de sustitución de cemento por CLD y carbonatadas. Relación a/c $=0,7$.

Figure 8. Evolution of Icorr in steel bars embedded in carbonated samples with 0, 10, 20, 30 and 60\% replacement of Portland cement mass by SSA. $w / b$ ratio $=0.7$. 


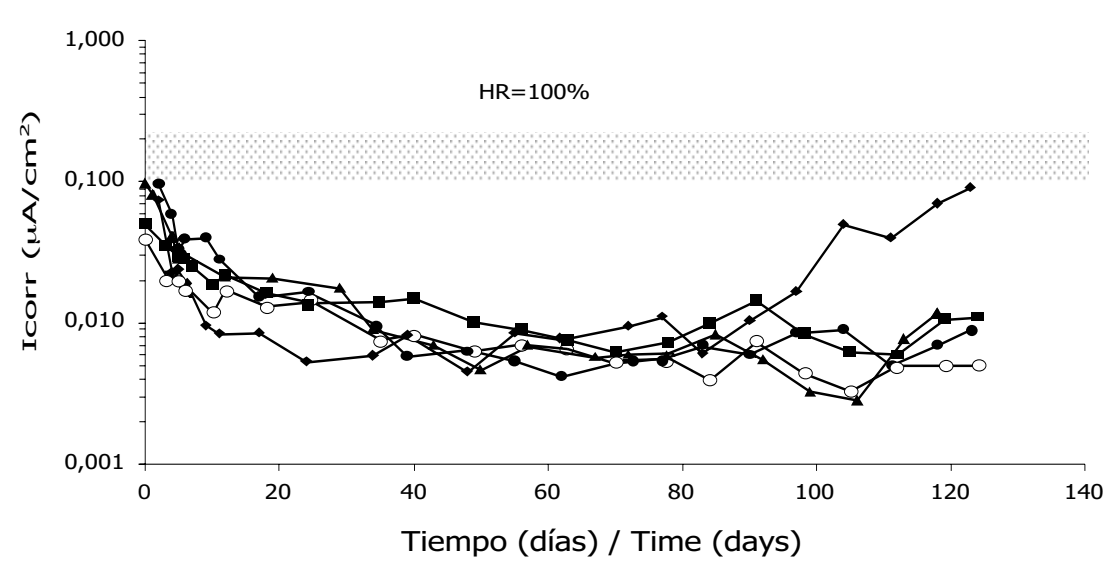

Figura 9. Evolución de los valores de Icorr de las armaduras de acero embebidas en probetas fabricadas con 0, 10, 20, 30 y $60 \%$ en masa de sustitución de cemento por CLD lavada con agua destilada. Relación a/c = 0,7 y $100 \% \mathrm{HR}$.

Figure 9. Evolution of Icorr in steel bars embedded in samples with 0, 10, 20, 30 and 60\% replacement of Portland cement mass by SSA washed with distilled water. $\mathrm{w} / \mathrm{b}$ ratio $=0.7$ and $100 \% \mathrm{RH}$.

lavada con agua desionizada tal y como se describe en el apartado 2.1. Se han fabricado probetas de mortero de idéntica formulación que las anteriores pero usando la ceniza lavada y se han sometido a atmósfera con $100 \%$ de HR. Los valores de $\mathrm{I}_{\text {corr }}$ para estas muestras, representados en la Figura 9, han sido medidos periódicamente durante un periodo de alrededor de tres meses.

En este caso, para cualquiera de los contenidos de CLD estudiados, los valores de $\mathrm{I}_{\text {corr }}$ se extienden por debajo de $0,1 \mu \mathrm{A} / \mathrm{cm}^{2}$, aunque los morteros con contenidos entre 0 y $30 \%$ de CLD han presentado velocidades de corrosión similares y bastante bajas. Conviene resaltar que los valores de $\mathrm{I}_{\text {corr }}$ en los morteros fabricados con CLD lavada han sido más bajos que en los fabricados con CLD sin lavar. Estos resultados demuestran que existe una influencia significativa de la concentración de sales solubles que posee la CLD sobre el proceso de corrosión del acero y que el proceso de lavado de la ceniza es una alternativa interesante para reducir el efecto potencial de dicha ceniza sobre la corrosión de las armaduras embebidas en los morteros fabricados con CLD.

\section{CONCLUSIONES}

1. La actividad puzolánica de la CLD en morteros de cemento Portland ha sido moderada de acuerdo a las propiedades mecánicas ofrecidas por estos morteros. En general, el mejor comportamiento se ha encontrado en los morteros en los que se ha sustituido un $10 \%$ en masa de cemento Portland por CLD y se han fabricado con una relación a/c de 0,5. corrosion. A series of mortar specimens made with washed SSA was stored in a wet closet at $100 \%$ RH. Figure 9 shows the $I_{\text {corr }}$ values found for the samples over a period of about three months.

Under these conditions, the $I_{\text {corr }}$ values were lower than $0.1 \mu \mathrm{A} / \mathrm{cm}^{2}$ for all SSA specimens, although they were lowest, and very similar, for the $0-30 \%$ SSA mortars. In all cases, the $I_{\text {corr }}$ values in mortars made with washed SSA were lower than in the respective samples containing non-washed ash. This supports the assumption that the soluble salt content in SSA has a significant effect on steel corrosion, and makes washing a promising alternative for reducing the potential corrosion of SSA in embedded steel bars.

\section{CONCLUSIONS}

1. The results of the mechanical tests revealed that SSA pozzolanic activity is moderate in PC mortars. Generally speaking, the mortars that performed best in this respect had $10 \%$ SSA and a $w / b$ ratio of 0.5 . 
2. En los morteros con sustitución parcial de cemento Portland por CLD aumenta el proceso de corrosión del acero embebido en los mismos cuando el porcentaje de sustitución es mayor del $10 \%$. No se observan diferencias significativas, en cuanto a su durabilidad entre aceros embebidos en morteros control y con un $10 \%$ de sustitución de CLD. Por tanto, en términos de corrosión del acero, el uso de la CLD es perfectamente factible.

3. La reducción de la concentración de sales en la CLD mediante lavado mejora el comportamiento frente a la corrosión de los morteros reforzados que la contienen y permite el uso de porcentajes de sustitución mayores siempre que sean admisibles las pérdidas de características mecánicas que ello conlleva.
2. Mixes containing over $10 \%$ SSA in place of Portland cement raised the steel corrosion rate in reinforced mortars. By contrast, when $10 \%$ or less of the cement mass was replaced with ash, steel durability was comparable to the findings for the control mortars. The use of SSA is therefore completely feasible from the standpoint of steel corrosion.

3. Washing SSA to reduce the soluble salt concentration improved the corrosion performance of reinforced mortars containing SSA admixtures and might be used to raise the allowable proportion of cement substitute where the concomitant loss of mechanical strength is not a concern.

\section{BIBLIOGRAFÍA/BIBLIOGRAPHY}

(1) Anderson, M., Skerratt, R. G., Thomas, J. P., Clay, S. D.: "Case study involving using fluidised bed incinerator sludge ash as a partial clay substitute in brick manufacture", Water Science Technology, vol. 34 (1996), pp. 507-515.

(2) Wiebusch, B. Seyfried, C. F.: "Utilization of sewage sludge ashes in the brick and tile industry", Water Science Technology, vol. 36 (1997), pp. 251-258.

(3) Lin, D. F., Weng, C. H.: "Use of sewage sludge ash as brick material", Journal of Environmental Engineering ASCE, vol. 127 (2001), pp. $922-927$.

(4) Bhatty, J. I., Reid, K. J.: "Compressive Strength of Municipal Sludge Ash Mortars", ACI Materials Journal (1989), pp. 394-400.

(5) Wainwright, P., Cresswell, D.: "Synthetic aggregates from combustion ashes using an innovative rotary kiln", Waste Management, vol. 21 (2001), pp. 241-246.

(6) Al Sayed, M. H., Madany, I. M.; Buali, A. R. M.: "Use of Sewage Sludge Ash in Asphaltic Paving Mixes in Hot Regions", Construction and Building Materials, vol. 9 (1995), pp. 19-23.

(7) Tay, J.: "Properties of Pulverized Sludge Ash Blended Cement", ACI Materials Journal (1987), pp. 358-364.

(8) Pinarli, V.: "Sustainable Waste Management - Studies on the use of sewage sludge ash in the construction industry as concrete material", en R. K. Dhir, T. D. Dyer, K. A. Paine, Thomas Telford (eds.): Proceedings Sustainable Construction. Use of incinerator ash, London, 2000, pp. 415-425.

(9) Monzó, J., Payá, J., Borrachero, M. V., Córcoles, A.: "Use of Sewage Sludge Ash (SSA)-Cement Admixtures in Mortars", Cem. Concr. Res., vol. 26 (1996), pp. 1389-1398.

(10) Monzó, J., Payá, J., Borrachero, M. V., Peris-Mora, E.: "Mechanical Behavior of Mortars Containing Sewage Sludge Ash (SSA) and Portland Cement with Different Tricalcium Aluminate Content", Cem. Concr. Res., vol. 29 (1999), pp. 87-94.

(11) Monzó, J., Payá, J., Borrachero, M. V., Córcoles, A.: "Reuse of sewage sludge ashes (SSA) in cement mixtures: The effect of SSA on the workability of cement mortars", Waste Management, vol. 23 (2003), pp. 373-381.

(12) Monzó, J., Payá, J., Borrachero, M. V., Bellver, A., Peris-Mora, E.: "Study of Cement-Based Mortars Containing Spanish Ground Sewage Sludge Ash", en J. J. J. M. Goumans, G. J. Senden, H. A. Van der Sloot (eds.), Proceedings of WASCON'97 Waste Materials in Construction: Putting theory into practice. Elsevier, Amsterdam, 1997, pp. 349-354.

(13) Pan, S. C., Tseng, D. H.: "Sewage sludge ash characteristics and its potential applications", Water Science and Technology, vol. 44 (2001), pp. 261-267.

(14) UNE-EN-196-1. Métodos de ensayos de cementos. Parte 1: Determinación de resistencias mecánicas.

(15) Stern, M., Geary, A. L.: "A theorical analysis of the shape of polarization curves", Journal Elec., vol. 104, no 1 (1957), p. 56.

(16) Stern, M., Weisert, E. D.: "Experimental observations on the relation between polarization resistance and corrosion rate", Proc. Am.

Soc. Test. Mater., vol. 59 (1959), p. 1280.

(17) Monzó, J., Payá, J., Borrachero, M. V.: "Experimental basic aspects for reusing sewage sludge ash (SSA) in concrete production", en R. K. Dhir y T. G. Jappy (eds.): Exploiting Wastes in Concrete, Thomas Telford, London, 1999, pp. 47-56.

(18) Andrade, C., González, J. A.: "Techniques electrochimiques qualitatives et quantitatives pour mésurer les effects des additions sur la corrosion des armatures", Silicates Industriales, vol. 47 (1982), pp. 289-295. 
